\title{
Relation between autophagy and the resistence of glioblastoma cells to temozolomide
}

\author{
Anália Carmo ${ }^{1 *}$, Helena Carvalheiro ${ }^{1}$, Maria C Lopes ${ }^{1,2}$ \\ From 16th International Charles Heidelberger Symposium on Cancer Research \\ Coimbra, Portugal. 26-28 September 2010
}

Gliomas are brain tumours that account for more than $50 \%$ of the tumours that arise within the central nervous system. They are highly proliferative, angiogenic, and develop resistance to the alkylating agents used in chemotherapy. The median survival time for glioma patients remains approximately 12-14 months in patients treated with temozolomide (TMZ) which is considered the main chemotherapeutic agent. In order to understand the cellular mechanisms involved in chemoresistance of glioma cells we analysed the activation of autophagy in cells treated with TMZ. In addition, we determined the effect of TMZ in the survival pathways PI3K/Akt and MAP kinases. For that, U-118 glioma cells were incubated with different concentrations of TMZ for different periods of time. Activation of autophagy and of PI3K/Akt and MAP kinase was evaluated by western blot. Apoptosis was addressed by confocal microscopy and by flow cytometry. The results indicated that in glioma cells treated with TMZ there was an increased expression of LC3 indicated that TMZ activated autophagy. Glioma cells presented a basal activation of PI3K/Akt and MAP kinases which was not blocked by TMZ. TMZ was also unable to induce apoptosis in a significant percentage of cells. Together, these results suggested that chemoresistance of glioma cells to TMZ is due to TMZ inability to block the activation of the survival pathways of autophagy, PI3K/Akt and MAP kinases.

\section{Author details}

${ }^{1}$ Center for Neuroscience and Cell Biology, University of Coimbra, Coimbra, Portugal. ${ }^{2}$ Faculty of Pharmacy, University of Coimbra, Coimbra, Portugal.

Published: 24 September 2010

\footnotetext{
* Correspondence: analiacarmo@gmail.com

'Center for Neuroscience and Cell Biology, University of Coimbra, Coimbra, Portugal

Full list of author information is available at the end of the article
}

References

1. Ziegler DS, Kung AL, Kieran MW: Anti-apoptosis mechanisms in malignant gliomas. J Clin Oncol 2008, 20:493-500.

2. Thorburn A: Apoptosis and autophagy: regulatory connections between two supposedly different processes. Apoptosis 2008, 13:1-9.

doi:10.1200/JCO.2007.13.9717

Cite this article as: Carmo et al:: Relation between autophagy and the resistence of glioblastoma cells to temozolomide. BMC Proceedings 2010 4(Suppl 2):P20.
Submit your next manuscript to BioMed Central and take full advantage of:

- Convenient online submission

- Thorough peer review

- No space constraints or color figure charges

- Immediate publication on acceptance

- Inclusion in PubMed, CAS, Scopus and Google Scholar

- Research which is freely available for redistribution

Submit your manuscript at www.biomedcentral.com/submit
C Biomed Central 